\title{
Quantification of geodetic risk factors occurring at the construction project preparation stage
}

\author{
Dariusz Skorupka ${ }^{1}$, Artur Duchaczek ${ }^{1}$, Magdalena Kowacka ${ }^{1, *}$, and Pawet Zagrodnik ${ }^{2}$ \\ ${ }^{1}$ General Tadeusz Kościuszko Military University of Land Forces, 109 Czajkowskiego Street, 51-147 Wrocław , Poland \\ ${ }^{2}$ Surveying Department, STRABAG Infrastruktura Południe Sp.z o.o., the Company STRABAG SE Group Wysoka, \\ 5A Lipowa Street, 52-200 Wrocław, Poland
}

\begin{abstract}
Land surveying is one of the elements of the execution of construction works. These include, among others, the establishment of a horizontal and vertical geodetic control network, an inventory of the existing area, development of a road project and setting out the location of the road in the area. In order to avoid mistakes, construction works should be controlled as part of surveying works during the implementation of a given project. The article attempts to identify and quantify risk factors occurring during surveying at the stage of preparing data from a detailed design. Two proprietary methods have been presented to calculate both the probability value and the consequences of individual risk factors. The advantage of the presented analyzes is the fact that the acquired validity hierarchy of risk factors, expressed in numerical values, can be explained in a scientific way, rather than referring only to possessed knowledge, experience and intuition.
\end{abstract}

\section{Introduction}

Identification of risk factors related to the execution of construction works imposes the necessity to undertake an in-depth review of the phenomenon in question as only the correct separation of those factors allows for a correct risk assessment.

Determination of risk factors is usually based on the analysis of experience from the implementation of projects with similar characteristics, as well as the knowledge of national and foreign experts and the analysis of the available statistical data. Risk factors can be divided into universal ones that may occur in the realization of the majority of construction projects and those that depend on the specifics of a given project $[7,19]$.

The article attempts to identify and quantify risk factors occurring during surveying at the stage of preparing data from a detailed design.

\section{Surveying works during the implementation of a road construction project}

Surveying works are indispensable when carrying out construction works. A preliminary analysis of the project as well as the verification of the route geometry or completeness of the documentation constitute just the beginning of the surveyor's tasks in this type of undertaking. Furthermore, geodetic works require the establishment of a geodetic horizontal and vertical control network, an inventory of the existing area, development of a road project and setting out the location of the road in the area. Construction works are controlled as part of surveying work also during the implementation of the project to ensure that mistakes are avoided. Finally, the acceptance documentation is developed [12, 14, 17].

The following risk factors included in the work are implemented at the stage of data preparation for a project:

- $\quad R_{1}$ - the incorrectly adopted horizontal layout - i.e. the project in the editable version is, for example, twisted, shifted relative to the real one, over scaled;

- $R_{2}$ - the incorrectly accepted altitude system for the development of data and the terrain elevation - e.g. Kronsztadt 60 frequently confused with Kronstadt, 86 ;

- $R_{3}$ - a failure to develop a master plan and then update it - which results in the lack of possibility for detecting design and execution errors affecting the implementation of other assortments, mainly collisions;

- $R_{4}$ - inability to obtain geodetic register of land utilities network information from the County Documentation Center of Geodesy and Cartography resources - which results in the lack of information about existing underground devices, and thus damage to "unknown" reinforcement;

- $R_{5}$ - development of a numerical terrain / project model - i.e. no control over connecting triangles through e.g. the generation of cross-sections, resulting in an erroneously formed solid; some

\footnotetext{
* Corresponding author: magdalena.kowacka@awl.edu.pl
} 
abnormalities cannot be seen in the overview of triangles or 3D solids.

In the subject literature, the concept of risk is understood and defined variously [5, 6, 10, 15, 16, 18]. Risk is a term generally known and often used by both practitioners and theoreticians in different areas of human activity. One could say that this fact alone determines the need to study the problem of risk.

Finally, the formula (1), previously applied in the work [1], was used in the article for the identification and quantification of risk.

In this formula, the risk $r_{\mathrm{i}}$ is calculated as the product of the probability $p_{\mathrm{i}}$ of this factor occurrence and the consequences $c_{\mathrm{i}}$ stemming from its occurrence divided by the sum of their products for all $n$ analyzed evaluation criteria [1]:

$$
r_{\mathrm{i}}=\frac{p_{\mathrm{i}} c_{\mathrm{i}}}{\sum_{j=1}^{j=n} p_{\mathrm{j}} c_{\mathrm{j}}}
$$

assuming that the value of the probability $p_{i}$ and the consequences $c_{\mathrm{i}}$ is a number in the range $<0 ; 1>$.

The values of probability $p_{\mathrm{i}}$ and the consequences $c_{\mathrm{i}}$ were determined using selected multi-objective optimization methods. Numerous methods of multiobjective optimization, which could be used to solve the subject matter, have been presented in the literature on the subject. Authors of various works have presented both classification and comparison of those methods $[11,13]$ therefore such information is not included in this work.

The simplicity and transparency of a given method is a crucial element, since they directly affect the willingness to use the method in engineering practice. Even the best method, if it is too complicated and not transparent, will not be used by engineers in everyday work practice. Therefore, such a method will prove unnecessary from the point of view of practical applications.

\section{Probability of occurrence of individual risk factors}

Considering the probability of occurrence of individual geodetic risk factors, it was assumed that this is the size determining our expectations as to the possibility of a given event occurrence. This value is therefore used to determine the possibility of an event occurring and takes values in the range $\langle 0 ; 1\rangle$. At the same time, it was assumed that the sum of these numbers always equals one $[1,2,3]$

Since determining the probability based only on subjective premises and feelings may not be unusable for engineering practice, it was necessary to indicate a method for identifying this probability. In the paper [3] authors presented the method of quantifying a decisionmaker's preferences during the risk assessment of bridges operation service. The authors have been adopted this method to quantify the probability of occurrence of individual geodetic risk factors at the stage of project execution.

The analysis starts with the creation of a square matrix $A$ called the matrix of direct influence of risk factors. The rows of this matrix are dedicated to the risk factors appearing in the comparisons first, while the columns are dedicated to the factors appearing in the comparisons as second.

The influence of individual risk factors on neighboring factors is realized through the allocation of appropriate numerical assessments. However, the adopted rating scale depends on a computational case under consideration. For identical relations of individual risk factors, a given expression of matrix $A$ takes the value of zero. The elevation of one risk factor over the other is expressed by positive numbers. If there are $n$ levels of the hierarchy of risk factors in the analyzed example, the maximum value of the elevation is $(n-1)$. The reduced significance of a given risk factor in relation to another factor is expressed by negative numbers.

The calculations start with completing the direct influence matrix $A$ with assessments determining the elevation of individual factors. Next, the matrix of direct influence is completed with negative evaluations corresponding to lowering the significance of individual risk factors, while calculating the sum of rows $w_{\mathrm{i}}$ and columns $k_{\mathrm{i}}$ of the direct influence matrix $A$. Verification of the correctness of the assessments introduced to the matrix of direct influence $A$ is limited to checking whether the sum of the row $w_{\mathrm{i}}$ is equal (but opposite in sign) to the value of the column $k_{\mathrm{i}}$ of this matrix.

The values of the sums of the rows $w_{\mathrm{i}}$ cannot be directly used as probability values for the occurrence $p_{i}$ of five individual risk factors. It was assumed that they should be numbers from 0 to 1 , while their sum should be equal to one. Therefore, it has been proposed to recalculate these values according to the relation [3]:

$$
p_{\mathrm{i}}=\alpha+\frac{(1-(\alpha \cdot n))\left(w_{\mathrm{i}}-w_{\min }\right)}{\sum_{i=1}^{n}\left(w_{\mathrm{i}}-w_{\min }\right)}
$$

where:

$w_{\min }$ - the lowest value from all calculated row totals $w_{\mathrm{i}}$, $n$ - the number of risk factors $R_{\mathrm{i}}$,

$\alpha$ - the minimal desired value of the coefficient of importance $\gamma_{\mathrm{i}}$, while $0 \leq \alpha \leq 1 / \mathrm{n}$.

The paper attempts to quantify the probability (possibility) of risk factors appearing during surveying works at the stage of data preparation for the detailed design. Figure 1 depicts the adopted hierarchy of the considered risk factors $\left(R_{1} \div R_{5}\right)$ presenting the subjective assessment of the decision-maker. Relations between individual risk factors are assigned to the assessments shown in the direct influence matrix $A$ (Table 1).

In order to verify the correctness of the introduced assessments into the matrix of direct influence $A$, the sums of individual rows $w_{\mathrm{i}}$ of the matrix of direct influence and the sums of individual columns $k_{\mathrm{i}}$ of this matrix were calculated (Table 1). Then, the necessary condition for evaluating the correctness of the 
assessments introduced to the matrix of direct influence was checked $\left(w_{\mathrm{i}}=-k_{\mathrm{i}}\right)$. The carried out analyzes confirmed the correctness of the data entered into the direct influence matrix.

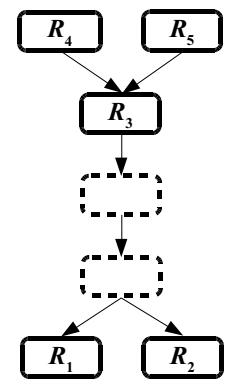

Fig. 1. The adopted risk factors hierarchy

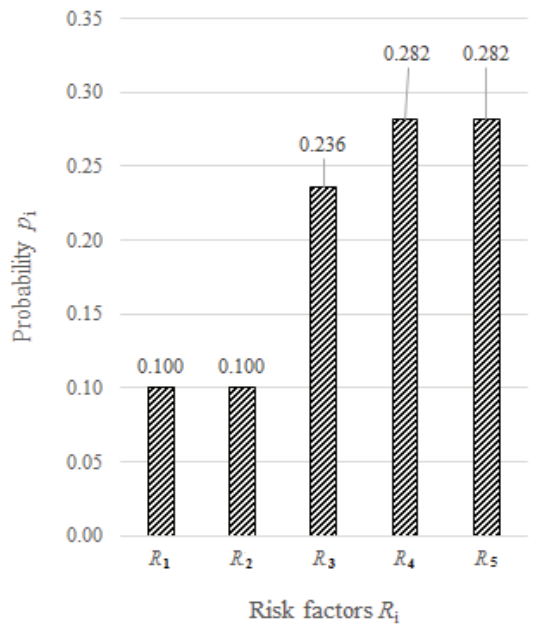

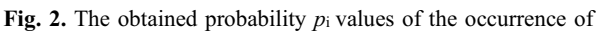
risk factors $R_{\mathrm{i}}$

Table 1. The values of elements of the "direct influence" matrix $A$

\begin{tabular}{|c|c|c|c|c|c|c|}
\hline $\begin{array}{c}\text { Risk } \\
\text { factors }\end{array}$ & $R_{1}$ & $R_{2}$ & $R_{3}$ & $R_{4}$ & $R_{5}$ & $w_{\mathrm{i}}$ \\
\hline$R_{1}$ & 0 & 0 & -3 & -4 & -4 & -11 \\
\hline$R_{2}$ & 0 & 0 & -3 & -4 & -4 & -11 \\
\hline$R_{3}$ & 3 & 3 & 0 & -1 & -1 & 4 \\
\hline$R_{4}$ & 4 & 4 & 1 & 0 & 0 & 9 \\
\hline$R_{5}$ & 4 & 4 & 1 & 0 & 0 & 9 \\
\hline$k_{\mathrm{i}}$ & 11 & 11 & -4 & -9 & -9 & ----- \\
\hline
\end{tabular}

Next, the probabilities $p_{\mathrm{i}}$ of the occurrence of individual risk factors were calculated using equation (2), assuming in the calculations that $\alpha$, i.e. the minimum desired value of $p_{\mathrm{i}}$, is 0.10 (Figure 2 and Table 2). The obtained hierarchy of results for individual risk factors and differences between individual levels of this hierarchy (i.e. 0.045454545 ) fully coincides with the hierarchy of factors presented in Figure 1 and Table 2.

Table 2. The obtained values of the probability $p_{\mathrm{i}}$ for individual risk factors

\begin{tabular}{|c|c|c|}
\hline $\begin{array}{c}\text { Risk } \\
\text { factors }\end{array}$ & $\begin{array}{c}\text { Values of the } \\
\text { probability } p_{\mathrm{i}}\end{array}$ & $\begin{array}{c}\text { Difference between } p_{\mathrm{i}} \text { at } \\
\text { adjacent levels of the } \\
\text { hierarchy }\end{array}$ \\
\hline$R_{4} / R_{5}$ & 0.281818182 & ------------- \\
\hline$R_{3}$ & 0.236363636 & 0.045454545 \\
$R_{1} / R_{2}$ & 0.1000000000 & $\begin{array}{c}0.136363636= \\
* 0.045454545\end{array}$ \\
& & ------------- \\
\hline
\end{tabular}

\section{Consequence of of individual risk factors}

occurrence

The objectivity of analyzes being conducted is always dependent on the adopted assessment criteria. The criteria accepted for calculating the risk of surveying works can be actually different in each case. However, one should be aware that too high a number of criteria impedes conducting analyzes in question. For this reason, the calculation included two basic criteria, namely time $\left(K_{1}\right)$ and costs $\left(K_{2}\right)$. The time $\left(K_{1}\right)$ concerned the delay in the implementation of the discussed projects, while the costs $\left(K_{2}\right)$ were related to the increase of financial resources allocated for the implementation of the project and resulting from the occurrence of a specific risk factor [4].

In this work, the proprietary method described in the paper [4] has been applied for this purpose. At the stage I of calculations, the requirements and constraints for future hypothetical variants of solutions to the analyzed problem are determined (the so-called boundary conditions), while the stage II is the definition of decision options available in given circumstances $\left(R_{1}\right.$, $\left.R_{2}, \ldots, R_{\mathrm{n}}\right)$. At the stage III, the adopted criteria $\left(K_{1}, K_{2}\right.$, $\left.\ldots, K_{\mathrm{m}}\right)$ and measurement units as well as the desired direction of change $\left(Z_{1}, Z_{2}, \ldots, Z_{\mathrm{m}}\right)$ within a given partial criterion ("MIN" - minimum or "MAX" - maximum) are specified in detail. To this end, the arithmetic mean $\beta_{\mathrm{j}}$ of the values of the analyzed variants in terms of individual criteria is first determined. Then, the auxiliary desired value $S_{\mathrm{j}}$ is defined. If $Z_{j}=M A X$, then $S_{\mathrm{j}}=2 \beta_{\mathrm{j}}$, whereas if $Z_{j}=M I N$, then $S_{\mathrm{j}}=0$.

The stage IV consists in setting the hierarchy of individual criteria by setting subjective values of weights given by a decision maker to the assumed assessment criteria $\left(\alpha_{1}, \alpha_{2}, \ldots, \alpha_{\mathrm{m}}\right)$. At the stage $\mathrm{V}$, the matrix $E$ is created, containing the actual values of the analyzed criteria in terms of particular variants.

At the stage VI, the length of the "distance" from the actual state to the most desirable state for a given criterion is determined. For this purpose, the actual value of a certain criterion should be subtracted from its desired value. When calculating the actual distance 
covered, the expressions of the matrix $P$ (stage VIa) are specified, then the matrix $P$ is normalized by dividing each element by the sum of elements in the column in which it is located. This creates the matrix $T$ (stage VIb).

At the stage VII, the numbers obtained at the stage VI are multiplied by weights adopted at the stage IV and thus the matrix $U$ is formed. The element $u_{\mathrm{ij}}$ of the matrix $U$ represents the so-called normalized length of the "distance" of the $i^{t h}$ decision variant to the adopted auxiliary desired value $S_{\mathrm{j}}$, taking into account the current preferences of the decision maker

The final stage (VIII) is the identification of the best option based on the so-called cumulative assessment $o_{\mathrm{i}}$, which is the sum of the ratings given to each option, with reference all the analyzed criteria.

In this task, the cumulative assessment $o_{\mathrm{i}}$ is considered as the value of the consequence $c_{\mathrm{i}}$ of a given risk factor occurrence during the surveying works at the stage of preparing data for a construction project.

Two criteria were adopted for the analyses purposes, i.e. extension periods of the project execution $\left(K_{1}\right)$ and an increase in its implementation costs $\left(K_{2}\right)$. The equivalence of both criteria was assumed for the calculations, i.e. the value of the coefficient of importance was 0.5 for each of the criteria. However, the minimization was the desired direction of changes in the values of the criteria being analyzed. Table 3 depicts the comparison of the criteria values for the analyzed risk factors for the adopted rating scale from 1-5. Tables 4-7 present the indirect results of the calculations.

Table 3. Values of criteria for individual risk factors (stage V)

\begin{tabular}{|c|c|c|}
\hline \multirow{2}{*}{ Risk factors } & \multicolumn{2}{|c|}{ Criteria } \\
\cline { 2 - 3 } & $K_{1}$ & $K_{2}$ \\
\hline$R_{1}$ & 1 & 4 \\
\hline$R_{2}$ & 1 & 4 \\
\hline$R_{3}$ & 5 & 5 \\
\hline$R_{4}$ & 4 & 4 \\
\hline$R_{5}$ & 3 & 4 \\
\hline
\end{tabular}

Table 4. The figures describing the length of the „distance" from the actual to the desirable state (stage VIa)

\begin{tabular}{|c|c|c|}
\hline \multirow{2}{*}{ Risk factors } & \multicolumn{2}{|c|}{ Criteria } \\
\cline { 2 - 3 } & $K_{1}$ & $K_{2}$ \\
\hline$R_{1}$ & -1.00 & -4.00 \\
\hline$R_{2}$ & -1.00 & -4.00 \\
\hline$R_{3}$ & -5.00 & -5.00 \\
\hline$R_{4}$ & -4.00 & -4.00 \\
\hline$R_{5}$ & -3.00 & -4.00 \\
\hline
\end{tabular}

Table 5. Results of normalisation of the data contained in Table 4 (stage VIb)

\begin{tabular}{|c|c|c|}
\hline \multirow{2}{*}{ Risk factors } & \multicolumn{2}{|c|}{ Criteria } \\
\cline { 2 - 3 } & $K_{1}$ & $K_{2}$ \\
\hline$R_{1}$ & 0.07143 & 0.19048 \\
\hline$R_{2}$ & 0.07143 & 0.19048 \\
\hline$R_{3}$ & 0.35714 & 0.23809 \\
\hline$R_{4}$ & 0.28571 & 0.19048 \\
\hline$R_{5}$ & 0.21428 & 0.19048 \\
\hline
\end{tabular}

Table 6. Data contained in Table 5 corresponding to weights accepted (stage VII)

\begin{tabular}{|c|c|c|}
\hline \multirow{2}{*}{ Risk factors } & \multicolumn{2}{|c|}{ Criteria } \\
\cline { 2 - 3 } & $K_{1}$ & $K_{2}$ \\
\hline$R_{1}$ & 0.03571 & 0.09524 \\
\hline$R_{2}$ & 0.03571 & 0.09524 \\
\hline$R_{3}$ & 0.17857 & 0.11905 \\
\hline$R_{4}$ & 0.14286 & 0.09524 \\
\hline$R_{5}$ & 0.10714 & 0.09524 \\
\hline
\end{tabular}

Table 7. Cumulative assessments resulting from calculations (stage VIII)

\begin{tabular}{|c|c|}
\hline Risk factors & Cumulative assessment $o_{\mathrm{i}}$ \\
\hline$R_{1}$ & 0.13095 \\
\hline$R_{2}$ & 0.13095 \\
\hline$R_{3}$ & 0.29762 \\
\hline$R_{4}$ & 0.23809 \\
\hline$R_{5}$ & 0.20238 \\
\hline
\end{tabular}

The values of the consequences $c_{\mathrm{i}}$ of the occurrence of risk factors $R_{\mathrm{i}}$ obtained from the calculations are presented in Figure 3. The carried out analysis shows that, taking into consideration the adopted criteria, the highest rating $c_{\mathrm{i}}$ has been assigned to the risk factor $R_{3}$, which means that the occurrence of this risk factor will have the greatest consequences on the change of project costs and its execution time.

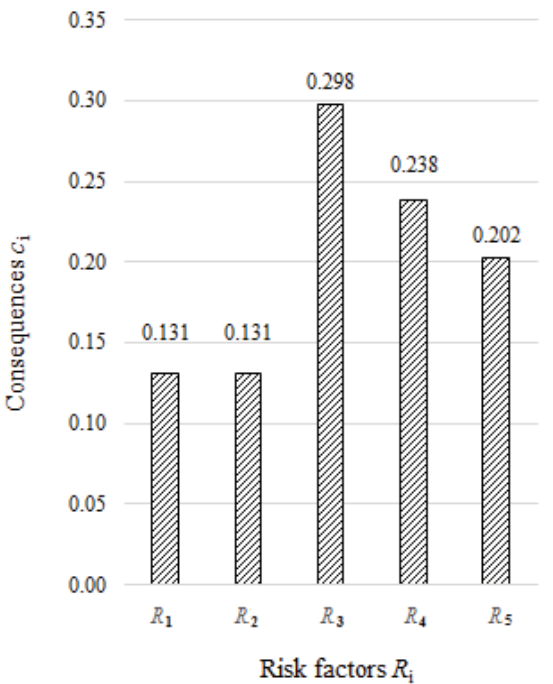

Fig. 3. The obtained values of the consequences $c_{i}$ of the occurrence of a given risk factor 


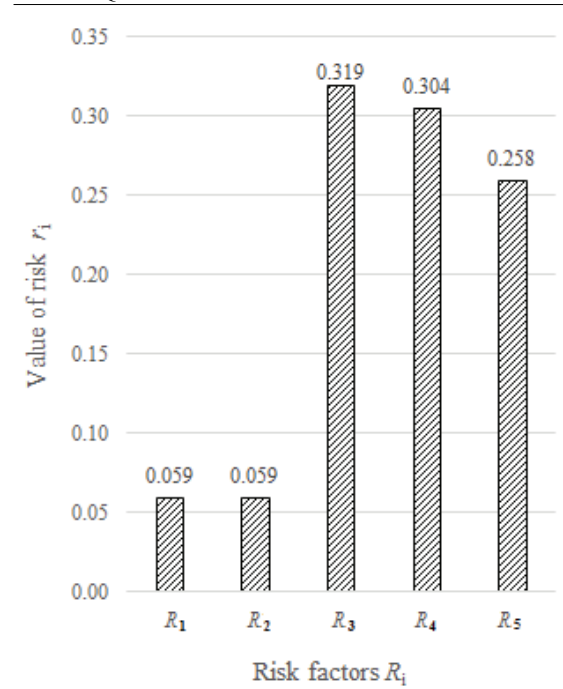

Fig. 4. The obtained values of the calculated risk values $r_{\mathrm{i}}$ for individual factors

\section{Conclusion}

An unusual application of two selected multi-objective optimization methods was presented to calculate the probability value $p_{\mathrm{i}}$ and the consequences $c_{\mathrm{i}}$. Then, the risk value $r_{\mathrm{i}}$ of a given factor (Figure 4) can be easily calculated using the formula (1).

The calculations show that the most essential risk factor in the project creation process is the lack of preparation of a master plan, and later its update - which leads to a failure to detect design and execution errors affecting the implementation of other assortments, mainly collisions $\left(R_{3}\right)$. It should also be noted that not much lower risk values were obtained for the risk factor R4, i.e. the lack of geodetic register of land utilities network information obtained from the County Documentation Center of Geodesy and Cartography resource - which results in information deficit about existing underground devices, and thus damage to "unknown" reinforcement. On the other hand, the incorrectly adopted horizontal system $\left(R_{1}\right)$ and the altitude system $\left(R_{2}\right)$ wrongly accepted for the development of data and terrain elevation are of marginal significance.

The advantage of the presented analyzes is the fact that the acquired validity hierarchy of risk factors, expressed in numerical values, can be explained in a scientific way, rather than referring only to possessed knowledge, experience and intuition. Another advantage of the proposed proprietary method is the fact that it eliminates the need to set numerical desirable and undesirable values of a particular criterion. A separate issue is to establish criteria for the evaluation of the analyzed risk factors. Firstly, it is often a matter of a decision maker's individual preferences. Secondly, it is often associated with the availability of relevant data. The proposed method can also be used in other areas of construction projects engineering.

The authors realize that the issue considered in this paper does not cover all aspects of risk assessment of geodetic works carried out at the stage of data preparation for a project, however it is undoubtedly a continuation and interesting extension of the discussed subject $[3,8,9,20]$.

\section{References}

1. A. Duchaczek, D. Skorupka, A Risk Assessment Method of Bridge Facilities Damage in the Aspect of Potential Terrorist Attacks. Periodica PolytechnicaCivil Engineering, vol. 60, issue 2, pp. 189-198 (2016)

2. A. Duchaczek, D. Skorupka, Risk Assessment as a Safety Element in Temporary Bridge Exploitation. European Journal of Environmental and Civil Engineering, vol. 21, issue 10, pp. 1253-1269 (2017)

3. A. Duchaczek, D. Skorupka, Ilościowe określenie preferencji decydenta podczas oceny ryzyka eksploatacji mostów. Czasopismo Materiały Budowlane, no 8, pp. 103-105 (2017)

4. A. Duchaczek, D. Skorupka, The Optimisation of the Selection of Means of Transport for the Implementation of Chosen Construction Projects. KSCE Journal of Civil Engineering (2018)

5. A. Leśniak, E. Plebankiewicz, Opóźnienia $w$ robotach budowlanych. Zeszyty Naukowe Wyższej Szkoły Oficerskiej Wojsk Lądowych, vol. 3 (157), pp. 332 - 339 (2010)

6. B. A. K. S. Perera, I. Dhanasinghe, R. Rameezdeen, Risk management in road construction: the case of Sri Lanka. International Journal of Strategic Property Management, vol. 13(2), pp. 87-102 (2009)

7. D. Skorupka, D. Kuchta, Metody oceny ryzyka w przedsięwzięciach budowlanych (2013)

8. D. Skorupka, A. Duchaczek, M. Kowacka, Determining the Hierarchy of Selected Geodetic Risk Factors for Linear Ventures, W: Proceedings of the International Conference on Numerical Analysis and Applied Mathematics 2017, Thessaloniki, Greece, September pp. 25-30 (2017)

9. D. Skorupka, M. Kowacka, Identification of risk factors of development and operation of roads in the light of surveying work. Archives of Civil Engineering, vol. 62, issue 2, pp. 183-190 (2016)

10. D. Vose. Risk analysis: a quantitative guide. John Wiley \& Sons (2008)

11. E. Ignasiak, Badania operacyjne. Państwowe Wydawnictwo Ekonomiczne, Warszawa (2001)

12. M. Ghorbani, M. Sharifzadeh, S. Yasrobi, M. Daiyan, Geotechnical, structural and geodetic measurements for conventional tunnelling hazards 
in urban areas - The case of Niayesh road tunnel project. Tunnelling and Underground Space Technology, vol. 31, pp. 1-8 (2012)

13. M. Książek, Analiza porównawcza wybranych metod wielokryterialnych oceny przedsięwzięć inwestycyjnych, Budownictwo i inżynieria środowiska, Politechnika Białostocka, No 2, pp. 555-561 (2011)

14. M. Kuburić, M. Lero, Surveying works in road designing and construction, Journal of Applied Engineering Science (Istraživanja i projektovanja za privredu), vol. 9, no. 3, pp 393-400 (2011)

15. O. Kapliński, Usefulness and credibility of scoring methods in construction industry, Journal of Civil Engineering and Management, vol. 14, pp. 21-28 (2008)

16. P. Jaśkowski, A. Sobotka, Scheduling construction projects with resources accessibility limited and changeable in time, Journal of Civil Engineering and Management, vol. 10, pp. 267-276 (2004)

17. R. Navon, Y. Shpatnitsky, A model for automated monitoring of road construction. Construction Management and Economics, vol. 23, iss. 9, pp. 941-951 (2005)

18. R. Sturk, L. Olsson, J. Johansson, Risk and decision analysis for large underground projects, as applied to the Stockholm ring road tunnels. Tunnelling and Underground Space Technology, vol. 11(2), pp. 157-164 (1996)

19. T. Kasprowicz, Inżynieria przedsięwzięć budowlanych. Wydział Inżynierii, Chemii i Fizyki Technicznej Wojskowej Akademii Technicznej (2002)

20. W. Bożejko, Z. Hejducki, M. Rogalska, P. Rajba, M. Wodecki, Harmonogramowanie robót budowlanych $w$ systemie potokowym $z$ niepewnymi danymi, Zeszyty Naukowe Wyższa Szkoła Oficerska Wojsk Lądowych im. gen. Tadeusza Kościuszki, No. 4 (166), 80-95 (2012) 